\title{
Effects of Triazole and Strobilurin-Based Fungicides on Fusarium culmorum on Wheat
}

\author{
Füsun Sukut ${ }^{1} \&$ Nagehan Desen Köycü ${ }^{2}$ \\ ${ }^{1}$ Natural and Applied Sciences Institute, Tekirdağ Namık Kema University, Tekirdağ, Turkey \\ ${ }^{2}$ Plant Protection Department, Agricultural Faculty, Tekirdağ Namık Kemal University, Tekirdağ, Turkey \\ Correspondence: Nagehan Desen Köycü, Plant Protection Department, Agricultural Faculty, Tekirdağ Namık \\ Kemal University, Tekirdağ, 59030, Turkey. E-mail: dkoycu@nku.edu.tr
}

\author{
Received: January 20, $2019 \quad$ Accepted: March 1, $2019 \quad$ Online Published: April 15, 2019 \\ doi:10.5539/jas.v11n5p16 URL: https://doi.org/10.5539/jas.v11n5p16
}

\begin{abstract}
Fusarium culmorum is an important pathogen, that causes pre and post-emergence death in seedlings from both seed and soil-borne sources, in addition to causing root, crown root and wheat head infections on wheat. Treatment of seeds with fungicides is especially important to inhibit seed originated seedling infections when cultural methods are ineffective against the infection of the pathogen in root and crown root and the lack of completely resistant wheat cultivars against this pathogen. The efficiency of fungicides with prothioconazole + tebuconazole and triticonazole + pyraclostrobin active ingredients, licensed on Fusarium spp. in seeds, on seed originated seedling infections of $F$. culmorum is determined in vitro and in vivo conditions. Seeds of Flamura- 85 bread wheat cultivar, naturally infected with F. culmorum S-14, were used in this study. The effect of treating seeds naturally infected with $F$. culmorum S-14 with fungicides on seed germination, root length, coleoptile length and disease severity was determined in the experiment in vitro. Germination rate of the seed was determined as $68 \%$ for triticonazole + pyraclostrobin and $43 \%$ for prothioconazole + tebuconazole, while disease severity was $42.70 \%$ and $61.30 \%$, respectively. While both fungicides were determined to be effective on the disease severity, the effect of triticonazole + pyraclostrobin on disease severity was found to be higher than prothioconazole + tebuconazole. Because of the higher rate of effectiveness of triticonazole + pyraclostrobin to prevent seed-borne infections in vitro conditions, it was determined that the fungicide causes an increase in germination rate with wet and dry weight of the seed, while significantly decreasing the disease severity, in the tests to determine the effectiveness of the fungicide in vivo conditions.
\end{abstract}

Keywords: Fusarium culmorum, fungicide, wheat

\section{Introduction}

Fusarium culmorum (W.G. Smith) Saccardo is an important soil/seed borne pathogen and causes head blight, root and root crown rot in wheat (Scherm et al., 2013). With the germination of conidies or long living chlamydospores in the period from wheat seed germination to spike emergence, infections might occur in the root, root crown and stem. Infections in seedling period mostly occur in coleoptile and/or root crown, because of 3-4 year longevity of pathogen chlamydospores in the soil. Infection symptoms, proceeding with the development of the plant, can also be observed after the tillering period. Bleached heads start to form on the plants with water stress related to the increase in the transpiration speed of plants. In Turkey, $50 \%$ crop loss is sometimes recorded in regions with high disease severity (Akgül, 2008; Anonymous, 2008). In highly humid Thrace region, it is the cause of economical losses in wheat by causing pre and post-emergence deaths originating from soil/seed-borne seedling infections. Cultural practices are not sufficient to control F. culmorum and natural conditions are suitable for disease development and there is no fully resistant cultivar against the agent (Scherm et al., 2013; Arıc1, 2006). Thus, it is obligatory to use fungicides to control the agent. Fungicide treatment of seeds against root and root crown infections of the pathogen is important to prevent seed-borne infections (Cook, 1986). When the fungicides from triazole group fungicides in Sterol biosynthesis inhibitors (SBI) fungicides such as prothioconazole, tebuconazole, and triticonazole and carboxin from succinate dehidrogenase inhibitor (SDHI), with systemic impact mechanism, are applied on the seed surface, they can effectively protect the seeds from soil/seed borne infections of $F$. culmorum by moving to cotyledon, embryo, rootlet and endosperm using the humidity in the soil (Delen, 2016). While triazole group fungicides prevent the 
formation of mycotoxins of wheat head blight agents $F$. culmorum and $F$. graminearum, they can also be effective on yield (Scherm et al., 2013). Hence, it is known that difenoconazole, diniconazole flutriafol, metconazole, propiconazole, prothioconazole, tebuconazole, triticonazole and prothioconazole + tebuconazole increases yield (Demirci \& Maden, 2006; Paul et al., 2010). First seed treatments against Fusarium culmorum in wheat have started with the licensing of carboxin + thiram in mixture form in 1993, in Turkey. Fungicide mixtures with the active ingredients prochloraz + triticonazole, prothioconazole + tebuconazole and triticonazole + pyraclostrobin were licensed in 2011, 2013 and 2015 respectively. Usage of these fungicides on wheat seeds is obligatory for wheat production in our region. However, it is found that the effectiveness of the seed fungicides on pathogen can change depending on soil/seed borne infections of F. culmorum (Köycü \& Sükut 2018). Determination of the effectiveness of fungicides with the active ingredients prothioconazole + tebuconazole and triticonazole + pyraclostrobin, licensed on Fusarium spp., on seed-borne infections of Fusarium culmorum, was the purpose of this study.

\section{Materials and Methods}

\subsection{Wheat Seeds}

F. culmorum S-14 isolate, determined as pathogenic in wheat (Köycü \& Özer 2014), was inoculated in $1 \times 10^{5}$ (Haidukowski et al., 2012) conidia/ml dose on anthesis (ZGS 64) (Zadoks et al., 1974) period Flamura-85 wheat cultivar with hand atomizer (Haidukowski et al., 2012). Inoculated heads were covered with clean polyethylene bags and left for incubation for 48 hours. Infected plant material from infected heads was named as FcT (positive control) and plant material from untreated heads were named as KT (negative control) at harvest.

\subsection{In Vitro Tests}

Active ingredients prothioconazole $150 \mathrm{~g} / \mathrm{L}+$ tebuconazole $20 \mathrm{~g} / \mathrm{L}$ (Lamardor News $170 \mathrm{FS}$; Bayer Crop Science) and triticonazole $80 \mathrm{~g} / \mathrm{L}+$ pyraclostrobin $40 \mathrm{~g} / \mathrm{L}$ (Insure Perform; Basf Turkey), which are licensed for Fusarium species, were used in seed treatment. These tests were conducted to determine the most effective fungicide to use in vivo tests. After disinfecting the surface of the seeds of FcT and $\mathrm{KT}$ seed materials with $1 \% \mathrm{NaOCl}$ solution for 3 minutes, they were cleaned in sterile distile water 2 times and dried on sterile blotting paper in sterile cabin. Dried seeds were treated with $50 \mathrm{ml} / 100 \mathrm{~kg}$ commercial doses of triticonazole + pyraclostrobin and prothiconazole + tebuconazole. Four layers of sterile blotting paper, wetted in sterile distile water, were placed in petri dishes with 20 seeds per petri dish. Seeds in control treatment were fungicide free. The seeds were incubated for 7 days under total darkness and $23 \pm 1^{\circ} \mathrm{C}$. At the end of the incubation period, germination rate (\%), root and coleoptile lengths $(\mathrm{cm})$ were determined from seeds with coleoptile 2 times longer than seed length. Disease severity was determined by comparing the necrosis on the root and coleoptile parts of the seed with a modified 0-5 scala (Wildermuth \& Mc Namara 1994) (Figure 1). Disease severity was calculated (Townsend \& Heuberger 1943). The experiment was conducted in randomised plot design with 5 repetition containing 2 petris in each repetition. Re-isolation of lesions on roots and coleoptiles of the plants were made using PDA (Potato Dextrose Agar, Merck) after the evaluation of disease severity. The experiment has been repeated twice.

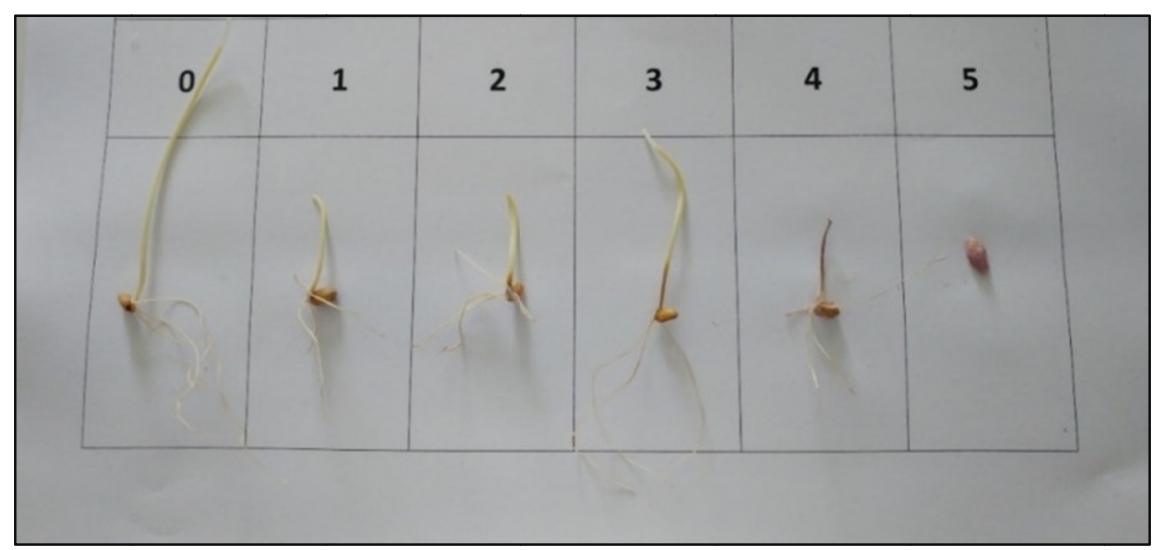

Figure 1. Descriptive scala used in the evaluation of disease severity ( 0 : healthy plant; 1 : Necrotic area is lower than $25 \%$ 2: Necrotic area is between $25-50 \% 3$ : Necrotic area is between $51-75 \%$ 4: Necrotic area is greater than $75 \%$ 5: Plant is dead) 


\subsection{In Vivo Tests}

Method for triticonazole + pyraclostrobin treatment of seeds infected with F. culmorum S-14 (FcT) in vitro was repeated in vivo. Seeds were sowed into sterile plastic pots $(12 \times 10 \mathrm{~cm})$ with $1 / 3$ mixture of sand and peat (Klasman-Deilmann), sterilized in otoclav, with 20 seeds in each pot. Untreated seeds were sowed into control pots. Pots were placed into a climate chamber with $23 \pm 1{ }^{\circ} \mathrm{C} 14: 10$ light: dark, $\% 80-90$ r.h. and 10000 lux light conditions and periodically irrigated with tap water. The experiments were conducted in randomised plot design with 5 repetition containing 2 pots in each repetition.

Plant emergence rates (\%) and (ZGS 12) (Zadoks et al., 1974), 15 and 30 days after sowing date, evaluation of disease severity (\%) on the roots and coleoptile parts of the seedlings according to the scala used in seed tests, plant height $(\mathrm{cm})$ (after root formation), wet and dry weights of plants were determined. Plants were dried in paper bags in a $50{ }^{\circ} \mathrm{C}$ stove for 72 hours and weighted to determine the dry weight. Re-isolation of lesions on roots and coleoptiles of the plants were made using PDA nutrient medium after the evaluation of disease severity.

\subsection{Statistic}

Effect of fungicides in vitro and in vivo was tested with Tukey test in SPSS (Version 18; IBM Corp., Armonk, NY).

\section{Results}

F-85 wheat seeds infected with F. culmorum FcT (pozitive control) and uninfected seeds KT (negative control) were used in field conditions for in vivo and in vitro tests.

\subsection{In Vitro Tests}

In vitro tests were made with the purpose of determining the most effective fungicide between prothioconazole + tebuconazole and triticonazole + pyraclostrobin active ingredient fungicides to use in vivo tests. After the germination of the naturally infected (F. culmorum S-14) some abnormal germinations in seeds (Figure 2) and necrosis in roots and coleoptile of the seeds were observed. In these observed abnormal germinations, only root or only coleoptile has formed in the some germinated seeds. In seeds with root formation, very short root development, only main root, main root +1 side root was observed and all roots have developed weakly.
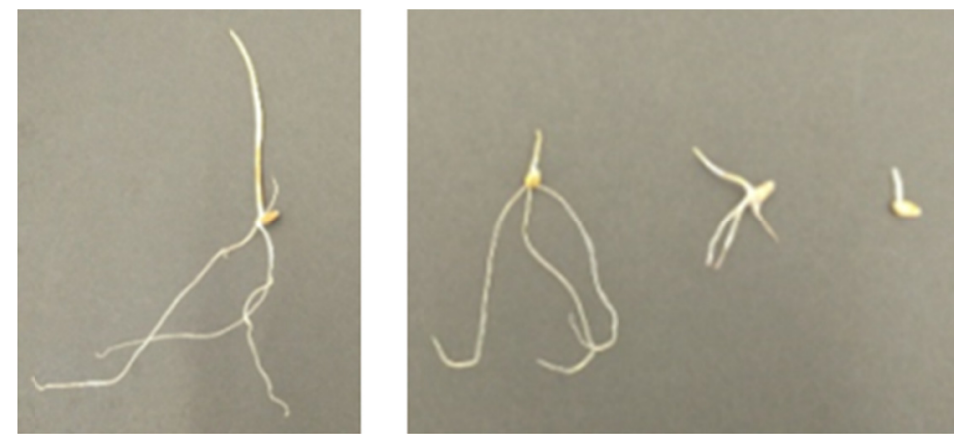

Figure 2. Germination of seeds a) control (left) b) infected with F. culmorum S-14 (right)

Germination rate, root and coleoptile length, disease severity of the seeds after treatment with triticonazole + pyraclostrobin and prothioconazole + tebuconazole were given in Table 1. While germination rates for these two fungicides were found to be $68 \%$ for triticonazole + pyraclostrobin and $43 \%$ for prothioconazole + tebuconazole, the difference between the germination rates of triticonazole + pyraclostrobin and positive control was found to be significant $(\mathrm{P}<0.05)$. The increase in germination of the seeds after treatment with triticonazole + pyraclostrobin was $38 \%$, while it was $13 \%$ after treatment with prothioconazole + tebuconazole. When root lenghts were evaluated, it was determine that the root length in positive control was $3.60 \mathrm{~cm}$, while it was respectively 5.07 and $4.74 \mathrm{~cm}$ in triticonazole + pyraclostrobin and prothioconazole + tebuconazole, with a significant difference between positive control and fungicide treatments $(\mathrm{P}<0.05)$. The effect of fungicides on coleoptile length has shown a significant difference between triticonazole + pyraclostrobin and positive control $(\mathrm{P}<0.05)$. Also, coleoptile length was found to be higher in fungicide treated seeds than negative control and fungicide treatment in infected seeds caused an increase in coeloptile length. The highest increase was in triticonazole + pyraclostrobin with $2.87 \mathrm{~cm}$. 
When the effect of fungicides on disease severity was evaluated, it was found that disease severity on fungicide treated seeds were respectively $61.30 \%$ and $42.70 \%$ in prothiconazole + tebuconazole and triticonazole + pyraclostrobin with a significant difference between fungicide treatments and positive control $(\mathrm{P}<0.05)$. Disease severity for triticonazole + pyraclostrobin and prothiconazole + tebuconazole was $49.22 \%$ and $27.11 \%$, respectively.

Table 1. The effect of fungicides on germination $(\%)$, root and coleoptile length $(\mathrm{cm})$ and disease severity $(\%)$ in infected seed with F. culmorum S-14

\begin{tabular}{lllll}
\hline Treatment & Germination rate $(\%)$ & Root length $(\mathrm{cm})$ & Coleoptile length $(\mathrm{cm})$ & Disease severity $(\%)$ \\
\hline Triticonazole + pyraclostrobin & $68 \mathrm{~b}^{*}$ & $5.07 \mathrm{~b}$ & $2.87 \mathrm{a}$ & $42.70 \mathrm{~b}$ \\
Prothioconazole + tebuconazole & $43 \mathrm{c}$ & $4.74 \mathrm{~b}$ & $2.63 \mathrm{ab}$ & $61.30 \mathrm{~b}$ \\
FcT (positive control) & $90 \mathrm{a}$ & $3.60 \mathrm{c}$ & $1.86 \mathrm{~b}$ & $84.10 \mathrm{a}$ \\
KT (negative control) & $91 \mathrm{a}$ & $7.26 \mathrm{a}$ & $2.58 \mathrm{ab}$ & $11.70 \mathrm{c}$ \\
\hline
\end{tabular}

Note. *Differences between means with different letters in the same column are significant according to Tukey multiple comparison test $(\mathrm{P}<0.05)$.

\subsection{In VivoTests}

Deformations were observed in the root crown of the seedlings caused by the pathogen in the pots. Root crown was found to be weaker in positive control seedlings than negative control seedlings and side roots were formed in addition to main root in some plants with brown necrosis on these roots (Figure 3). In some seedlings developed from fungicide treated seeds, even though the root crown was weakly developed, there wasn't any necrosis on these root crowns.

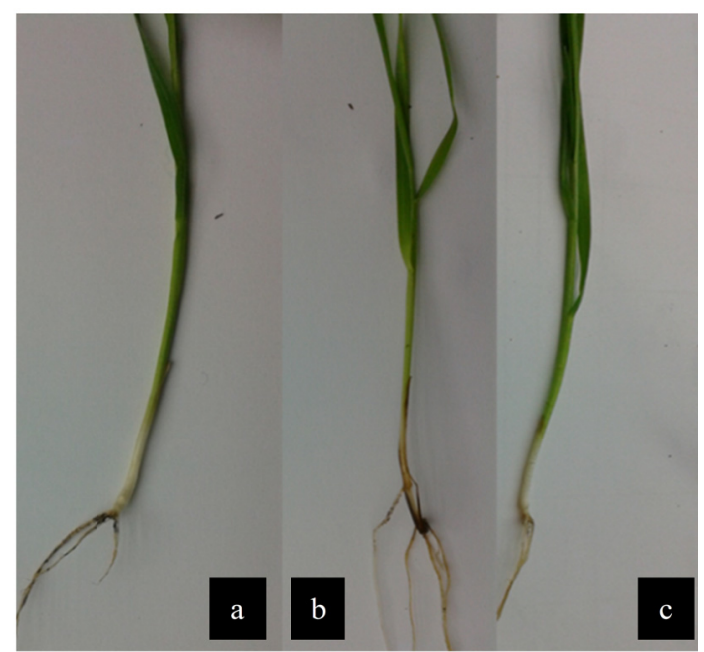

Figure 3. (a) negative control; (b) positive control; (c) triticonazole + pyraclostrobin

Effect of triticonazole + pyraclostrobin on seedling emergence after 15 days from sowing, seedling height after 30 days from sowing $(\mathrm{cm})$, disease severity $(\%)$, wet and dry weight $(\mathrm{g})$ was determined (Table 2). Seedling emergence rate was $96 \%$ in negative control, $46 \%$ in positive control, $79 \%$ in triticonazole + pyraclostrobin. There was a 50\% decrease in seedling emergence in seeds infected with $F$. culmorum when compared to negative control. Fungicide treatments on infected seeds were $44.17 \%$ effective and caused a $33 \%$ increase in seedling emergence. When the effect of fungicide on seedling height was examined, the difference between negative and positive control was not significant, while it was significant between triticonazole + pyraclostrobin and positive control $(\mathrm{P}<0.05)$. Plant height was approximately $34 \mathrm{~cm}$ in positive and negative control, while it was $36.04 \mathrm{~cm}$ in triticonazole + pyraclostrobin, which showed that the fungicide helps in increasing the plant height.

The wet weight of the seedlings was $0.51 \mathrm{~g}$ in negative control, $0.31 \mathrm{~g}$ in positive control and $0.52 \mathrm{~g}$ after triticonazole + pyraclostrobin treatment, with a significant difference between triticonazole + pyraclostrobin and positive control $(\mathrm{P}<0.05)$. Even though the difference between fungicide treatment and negative control was not 
significant, wet weight of the seedling after fungicide treatment was found to be higher than negative control. When the effect of fungicide on dry weight of the seedlings was investigated, it was determined that the dry weight of the seedling was $0.06 \mathrm{~g}$ in negative control, $0.04 \mathrm{~g}$ in positive control and $0.06 \mathrm{~g}$ after triticonazole + pyraclostrobin treatment, with a significant difference between positive control and triticonazole + pyraclostrobin $(\mathrm{P}<0.05)$. Disease severity was $6.18 \%$ in negative control, $32.03 \%$ in positive control and $8.75 \%$ in triticonazole + pyraclostrobin treatment. The effect of the fungicide on the disease was found to be $72.68 \%$ and there was a significant difference between the fungicide and positive control $(\mathrm{P}<0.05)$. Fungicide treatment was found to be very effective at decreasing the develpment of the disease and there was no significant difference between the fungicide and negative control. Pathogen was obtained from the re-isolation of necrosis on the root and root crown of the seedlings.

Table 2. The effect of triticonazole + pyraclostrobin on seedling emergence rate $(\%)$, plant height $(\mathrm{cm})$, wet and dry weight $(\mathrm{g})$, disease severity $(\%)$

\begin{tabular}{llllll}
\hline Treatment & Seedling emergence rate (\%) & Plant height $(\mathrm{cm})$ & Wet weight $(\mathrm{g})$ & Dry wet $(\mathrm{g})$ & Disease severity $(\%)$ \\
\hline Triticonazole + pyraclostrobin & $79 \mathrm{~b}^{*}$ & $36.04 \mathrm{a}$ & $0.52 \mathrm{a}$ & $0.06 \mathrm{a}$ & $8.75 \mathrm{~b}$ \\
FcT (positive control) & $46 \mathrm{c}$ & $34.32 \mathrm{~b}$ & $0.31 \mathrm{~b}$ & $0.04 \mathrm{~b}$ & $32.03 \mathrm{a}$ \\
KT (negative control) & $96 \mathrm{a}$ & $34.49 \mathrm{ab}$ & $0.51 \mathrm{a}$ & $0.06 \mathrm{a}$ & $6.18 \mathrm{~b}$ \\
\hline
\end{tabular}

Note. ${ }^{*}$ Differences between means with different letters in the same column are significant according to Tukey multiple comparison test $(\mathrm{P}<0.05)$.

\section{Discussion}

F. culmorum causes regression in development of root and stem, decrease in tillering, head formation and kernel formation by limiting water and nutrition movement in the plant with relation to infection severity (Wojciechowski et al., 1997; Bağc1 et al., 2001; Hekimhan et al., 2005; Mert-Türk et al., 2013; Scherm et al., 2013). Crop losses are economically important because of the severe infections especially in seedling period, in our country (Finci, 1979; Demirci, 2003; Arıc1, 2006; Araz et al., 2009; Köycü \& Özer, 2014). Thus, knowing the effectiveness of fungicides used against $F$. culmorum on disease severity is important to prevent plant deaths from seed-borne infections especially in pre and post-emergence in infected seeds. Hence, treatment of the seeds infected with $F$. culmorum by fungicides with carboxin, difenoconazole, diniconazole, tebuconazole, thiabendazole, fludioxonil + metalaxyl-M and tebuconazole + metalaxyl-M active ingredients is known to be effective on disease severity and increases product quality (Arslan \& Baykal 2002; Balmas et al., 2006; Hekimhan et al., 2007; Pariyar et al., 2014; Toçan, 2014; Köycü \& Sukut, 2018), while the effectiveness of the fungicides can change in relation to the sensitivity of the cultivar and different isolates of the pathogen (Akgül 2008; Spolti et al., 2013; Serfling \& Ordon, 2014). Likewise, Akgül (2008) has found that the effect of prothioconazole + tebuconazole (Lamardor FS 400, Bayer Crop Science) on seedlings developed from treated seeds against $F$. culmorum has changed between $11-12 \%$. In our study, we found that the same fungicide's effectiveness was around $27 \%$ on the pathogen.

Water content of the wheat seedlings can be determined with wet weight measurement, while the organic and inorganic compounds (nutritinal elements like phosphorus, potassium, calcium, copper, magnesium) without water can be determined with dry weight measurement (Karman, 2012). According to the results of our study, we concluded that the increase in wet and dry weight of the seedlings caused by the positive effect of triticonazole + pyraclostrobin would also increase the yield in field conditions.

\section{Conclusion}

In conclusion, fungicide with triticonazole + pyraclostrobin active ingredient is effective at the seed-borne infections of the pathogen on seedling development. Also, it was determined that the effect of the fungicides on the pathogen may change with the virulence of the pathogen, active ingredient of the fungicide used on the seed, weath cultivar and the seed infection method of the pathogen.

\section{Acknowledgements}

We would like to thank Matias Pasquali (Département Environnement et Agro-biotechnologies (EVA) Centre de Recherche Public-Gabriel Lippmann 41, ruedu Brill L-4422 Belvaux, Grand-duchy of Luxembourg) for performing the identification of the F. culmorum S-14 isolate. 


\section{References}

Akgül, D. S. (2008). The status of the root, crown and foot rot disease in wheat growing areas of Çukurova Region, determination of cultivar, effect of some fertilization and fungicide applications on disease development (Phd Thesis, Institute of Natural and Applied Science, Department of Plant Protection, University of Çukurova, Turkey).

Anonymous. (2008). Ministry of Food, Agriculture and Livestock, General Directorate of Agricultural Researches and Policies, Department of Plant Health Investigations. Retrieved from https://www.tarim. gov.tr/TAGEM/Belags/Technical\%20tal\%C4\%B1matlar\%202008/C\%C4\%B0LT\%201.pdf

Araz, A., Bayram, M. E., \& Babaroğlu, E. N. (2009). Determination of Disease Agents Which Cause Root and Foot-Rot Diseases in Some Wheat Varieties of Sakarya Province. Plant Protection Bulletin, 49(1), 31-43.

Arıc1, S. E. (2006). In vitro selection for resistans to head blight (Fusarium spp.) via somaclonal variation in wheat (Triticum aestivum L.) (Phd Thesis, Institute of Natural and Applied Sciences, Department of Plant Protection, University of Çukurova, Turkey).

Arslan, U., \& Baykal, N. (2002). Reactions of some wheat cultivars against root and crown rot fungal pathogens and efficacy of seed protectant fungicides to Fusarium culmorum (W.G.Sm.) Sacc. Journal of Agricultural Faculty of Uludăg University, 16, 69-76.

Bağcı, S. A., Hekimhan, H., Mergoum, M., Aktaş, H., Taner, S., Tulukçu, E., \& Ekiz, H. (2001). Effects of root and root rot of sprout factors on the yield of some grain genotypes and identification of durability sources. Turkey $4^{\text {th }}$ Field Crops Congress, Tekirdağ, Turkey.

Balmas, V., Delogu, G., Sposito, S., Rau, D., \& Migheli, Q. (2006). Use of a complexation of tebuconazole with â-Cyclodextrin for controlling foot and crown rot of durum wheat incited by Fusarium culmorum. Journal of Agricultural Food Chemistry, 54, 480-484. https://doi.org/10.1021/jf0523014

Cook, J. (1986). Wheat Management Systems in the Pacific Northwest. Plant Disease, 70, $894-898$. https://doi.org/10.1094/PD-70-894

Delen, N., (2016). Fungicides (p. 534, No. 1441). Nobel Press, Turkey.

Demirci, F. (2003). Determination of the reactions of some wheat cultivars agains troot and crown rot diseases caused by Fusarium spp. and Bipolaris sorokiniana. Journal of Agricultural Sciences, 9(4), 450-466.

Demirci, F., \& Maden, S. (2006). Effects of triazole fungicides on germination and emergence of wheat seeds. Journal of Agricultural Sciences, 12(2), 144-150.

Finci, S. (1979). Root and root diseases of wheat and safeguard remedies. Farmer Brochure, 21 (p. 15). Ministry of Food, Agriculture and Livestock General Directorate of Plant Protection and Agricultural Quarantine.

Haidukowski, M., Visconti, A., Perrone, G., Vanadia, S., Pancaldi, D., Covarelli, L., ... Pascale, M. (2012). Effect of prothioconazole-based fungicides on Fusarium head blight grain yield and deoxynivalenol accumulation in wheat under field conditions. Phytopathologia Mediterranea, 51(1), 236-246.

Hekimhan, H., Bağc1, S. A., Aktaş, H., Nicol, J. M., Aydoğdu, M., \& Akbudak, A. (2007). The effect of some fungicides on yield potential and dryland root and foot rot infection of Selcuklu-97 and Seri-82 wheat varieties (p. 321). Turkey $2^{\text {th }}$ Plant Protection Congress of Turkey, August 27-29, 2007, Isparta, Turkey.

Hekimhan, H., Bağcı, S. A., Nicol, J., \& Tunalı, B. (2005). Effects of root and root rot diseases on some winter cereal yields (pp. 201-206). Turkey $6^{\text {th }}$ Field Crops Congress, September 5-9, 2005, Antalya, Turkey.

Karman, A. R. (2012). Plant Nutrition (p. 1066). Gaziosmanpaşa University, Faculty of Agriculture, Turkey.

Köycü, N. D., \& Özer, N. (2014). Determination of resistance in some wheat cultivars against Fusarium spp. isolates in Trakya region of Turkey. Abstracts of invited lectures, oral and poster presentations given at the Joint International Congress: $14^{\text {th }}$ Congress of the Mediterranean Phytopathological Union and International Society of Mycotoxicology (Mediterranean Branch) meeting, Istanbul, Turkey, August 25-29, 2014. Phytopathologia Mediterranea, 54(1), 140-196.

Köycü, N. D., \& Sukut, F. (2018). Effect of unregistrated fungicides to Fusarium culmorum on wheat. Journal of Tekirdă Agricultural Faculty, 15(2), 26-35.

Mert-Türk, F., Kahraman, F., Gencer, R., \& Egese, C. Ö. (2013). Effect of Fusarium head blight on total protein and carbonhydrate contents of wheat. Yüzüncü Yıl University Journal of Agricultural Sciences, 23(2), 149-153. 
Pariyar, S. R., Dababat, A. A., Nicol, J. M., Erginbas-Orakci, G., Goll, M. B., Watrin, C., \& Sikora, R. (2014). Fungicide seed treatment and host resistance for the management of wheat crown rot caused by Fusarium culmorum. Basic Research Journal of Agricultural Science and Review, 3(9), 116-121.

Paul, P. A., McMullen, M. P., Hershman, D. E., \& Madden, L. V. (2010). Meta-analysis of the effects of triazole-based fungicides on wheat yield and test weight as influenced by Fusarium head blight intensity. Disease Control and Pest Management, 100, 160-171. https://doi.org/10.1094/PHYTO-100-2-0160

Scherm, B., Balmas, V., Spanu, F., Pani, G., Delogu, G., Pasquali, M., \& Migheli, Q. (2013). Fusarium culmorum: Causal agent of foot and root rot and head blight on wheat. Molecular Plant Pathology, 14(4), 323-341. https://doi.org/10.1111/mpp.12011

Serfling, A., \& Ordon, F. (2014). Virulence and toxin synthesis of an azole insensitive Fusarium culmorum Strain in wheat cultivars with different levels of resistance to Fusarium head blight. Plant Pathology, 63, 1230-1240. https://doi.org/10.1111/ppa.12203

Spolti, P., Guerra, D. S., Badiale-Furlong, E., \& Del Ponte, E. M. (2013). Single and sequential applications of metconazolealone or in mixture with pyraclostrobin to improve Fusarium head blight control and wheat yield in Brazil. Tropical Plant Pathology, 38(2), 085-096. https://doi.org/10.1590/S1982-56762013000 200001

Toçan, T. (2014). Determination of the effect of tebuconazole on mycelia growth and conidium germination of Fusarium culmorum in vitro condition (Master Thesis, Istanbul University, Institute of Science and Technology, Turkey).

Townsend, G. K., \& Heuberger, J. W. (1943). Methods for estimating losses caused by diseases in fungicide experiments. Plant Disease Report, 27, 340-343.

Wildermuth, G. B., \& McNamara, R. B. (1994). Testing wheat seedlings for resistance to crown rot caused by Fusarium graminearum Group 1. Plant Disease, 78, 949-953. https://doi.org/10.1094/PD-78-0949

Wojciechowski, S., Chelkowski, .J, Ponitka, A., \& Slusarkiewicz-Jarzina, A. (1997). Evaluation of spring and winter wheat reaction to Fusarium culmorum and Fusarium avenaceum. Journal of Phytopathology, 145, 99-103. https://doi.org/10.1111/j.1439-0434.1997.tb00370.x

Zadoks, J. C., Chang, T. T., \& Konzak, C. F. (1974). A decimal code for the growth stages of cereals. Weed Research, 14, 415-421. https://doi.org/10.1111/j.1365-3180.1974.tb01084.x

\section{Copyrights}

Copyright for this article is retained by the author(s), with first publication rights granted to the journal.

This is an open-access article distributed under the terms and conditions of the Creative Commons Attribution license (http://creativecommons.org/Licenses/by/4.0/). 